http://journals.ums.ac.id/index.php/ijolae

\title{
Self-Governance: Internationalization Management of Distinctive Higher Education Towards The World Class University
}

\author{
Djalal Fuadi', Harsono ${ }^{2}$, Muhammad Fahmi Johan Syah ${ }^{3}$, Agus Susilo ${ }^{4}$, Samsudin \\ Suhaili ${ }^{5}$, Budi Wahyono ${ }^{6}$ \\ ${ }^{1-4}$ Faculty of Teacher Training and Education, Universitas Muhammadiyah Surakarta, Indone- \\ sia \\ ${ }^{5}$ Fakulti Sains Kemanusiaan, Universiti Pendidikan Sultan Idris, Malaysia \\ ${ }^{6}$ Graduate School of East Asian Studies, Yamaguchi University, Japan
}

DOI: 10.23917/ijolae.v3i2.11754

Received: August 22 ${ }^{\text {nd }}, 2020$. Revised: December 19 ${ }^{\text {th }}, 2020$. Accepted: December 23 ${ }^{\text {rd }}, 2020$.

Available Online: January $11^{\text {st }}, 2021$. Published Regularly: May $1^{\text {st }}, 2021$.

\begin{abstract}
The purpose of this study is to describe the management of the internationalization process of higher education in the form of self-governance, strategic plans (vision, mission, and objectives), institutional management, curriculum and learning processes, and quality assurance. The research applied a qualitative approach. The scope of the research is limited to the policy/ legal framework for managing the internationalization of higher education at three Islamic universities in Yogyakarta, comprising the State Islamic University of Sunan Kalijaga Yogyakarta, the Islamic University of Indonesia, and the Muhammadiyah University of Yogyakarta. The data collection was conducted through the techniques of; (1) participant observation, (2) in-depth interviews, and (3) document study. The data analyses used are (1) on-site data analysis and (2) cross-site data analysis. The results of the study showed that the process of self-governance towards higher education institutions with international competitiveness was divided into several stages, namely: determination of the vision, mission, and objectives; development of learning and curriculum which are equivalent to foreign universities; recruitment of foreign students and lecturers; and quality assurance that prioritizes technology, ISO standards, orientation changes, and overall quality assurance. The self-governance accommodates the rapid change and unpredictable education situation due to many factors such as technology, social changes, society health issue, and disruption advanced education in pandemic era. In the context of tertiary management, distinctive competences in the future need to be adapted to distinctive management courtesy. For example, the internalization of speech acts according to local culture is one of the characteristics that can improve the sustainability of higher education.
\end{abstract}

Keywords: internationalization of higher education, advanced education, distinctive higher education, curriculum changes

Corresponding Author:

Djalal Fuadi, Teacher Training and Education Faculty, Universitas Muhammadyah Surakarta, Indonesia

Email: djalal.fuadi@ums.ac.id

\section{Introduction}

Accessible high quality of higher educa-

tion for all people in Indonesia remains minimal (Fadhil \& Sabic-El-Rayess, 2021). Besides, the obstacle encountered by the higher education itself is the difficulty of financing, thus burdensome to develop it into a highquality university. Sakernas data (2004) show that $73 \%$ of D1 and D2 graduates, $83 \%$ of D3 graduates, and $82.4 \%$ of S1 graduates were unemployed. The data show a big discrepancy between the expectation of becoming a successful person and the reality of finding a job. A higher level of education does not equal to the ability to get (let alone create) a job. Sakernas data also show that only $5.1 \%$ of D1 
and $\mathrm{D} 2$ graduates were able to open their own business, while $6.3 \%$ of D3 graduates could open independent business, and only $5.8 \%$ of $\mathrm{S} 1$ graduates managed to do so. Besides, Indonesian manpower based on the educational level as recorded in the Official Statistic News Number 41/05/Year XXII, 6 May 2019, as of February 2019 is: university as many as 12.61 million people or $9.75 \%$; Diploma I/II/III as many as 3.65 million people $(2.82 \%)$; SMK (Vocational High School) as many as 14.63 million people (11.31\%) and SMA (High School) consisting of 23.10 million people (17.86\%); SMP (Junior High School) with 22.97 million people (17.75\%); and SD (Elementary School) comprising under 52.40 million people or $40.51 \%$.

Education and health are components of the Human Development Index (HDI). Two components within aim to measure the country's ability to improve the lives of its citizens without the benefits of high income or fast economic growth. These two components have an important role in measuring the total HDI. The Philippines has a lower HDI ranking compared to Indonesia though its GNI, life expectancy at birth, and years of schooling are lower than that of Indonesia. By increasing the skills and knowledge, Indonesian's productivity can increase which in turn increases national productivity and Indonesia's competitiveness. If they compete in the job market, the government can provide them more education and more opportunities in the exam test for skill enhancement (Bernal \& Penney, 2019).

The tendency to reform higher education governance has now become a world trend. In Indonesia, the idea to perform higher education autonomy is driven by demands for democratization and autonomy in various sectors. The stipulation of the Draft Law on Education Legal Entities (RUU BHP) in 2004 was promoted by the existence of the Higher
Education Long Term Strategy (HELTS 2010-2014), a new chapter in the education sector in Indonesia, and a new direction for the journey of educational development in Indonesia. One of the prog-rams is the structurization of higher education institutions that are robust, efficient, and accountable. However, in practice, the implementation of various education policies, especially in higher education, has been very slow and leaves many obstacles and problems such as the assessment implementation (Stough et al., 2017).

As a result of globalization, the development of higher education requires universities to internationalize and demands higher education management based on management that is innovative, the use of information technology, intelligence, globaloriented, and graduates and research works that can be adopted by the international community. Determination of university rankings, either at the international level (World Class University) or at the national or Asean level through the Ranking of the Web of Universities from various continents, has become a new trend in measuring the quality of higher education from various aspects and perspectives, including reputation that can be achieved unequivocally by universities. This trend not only forces universities to compete for earning the rankings but also for improving the quality and be recognized at the international level (Lorenz, Ramsey, \& Richey, 2018).

The internationalization of higher education is a process involving the internationalization of the curriculum, administration and management, collabo-rative academic research, and student and lecturer exchanges (Jun Liu, Zhongxin, 2011). Internationalization is a process in which the government can better direct its readiness towards the globalization process (van der 
Wende, 2007). Higher education must always be able to improve towards an international direction by allowing as many students as possible to foreign countries to take part in educational programs. In other words, using the internet to obtain some course material to various campuses and colleges in other countries. 'Internationalization is a process that governments can steer more readily than globalization .... In this sense, higher education has become increasingly international in the past decade as more and more students choose to study abroad, enroll in foreign educational programmes and institutions in their home country, or simply use the Internet to take courses at colleges or universities in other countries.'

Several countries have responded to various systems and developed institutions towards globalization by conditioning the system through national system reforms carried out by the state, especially in organization and institutional management aspects (OECD, 2009). To achieve a worldclass level, universities must do reformation so that they could report global competitiveness in the implementation of their education and the quality of the education process. In achieving world-class universities, universities remain independent in maintaining the existence of their local culture (Indonesian values) into the world level education (global education). For instance, China, showing the success of higher education is the balance between the local culture and global expectation, according to Li, Sanders, \& Frenkel (2012).

Several universities in Indonesia have acknowledged that position so that many universities, in the implementation of their education, have managed various international activities, ranging from cooperation, the opening of international classes and programs, various seminars and international studies, to student exchanges, offshore campuses, and double degree programs. Three of the universities in Yogyakarta have performed internatio-nalization program for their education. However, the strategies, operations, and pressure points of the internationalization programs of the three universities somehow show intriguing differences to be studied further. These changes correspond to Higher Education (HE) Reformed by Scott P (2000). This is the result of a study from the perspective of world universities (PT) in making changes. These changes include: (1) higher education views, (2) organizational culture, (3) planning strategies, (4) allocation of financial resources, (5) financial mana-gement, (6) policies and committees, (7) personnel management, and (8) student management.

Good institutional management (good governance) can improve performance in various fields such as economy (Albassam, 2019) and government institutions (Klusá et al., 2018) as well as people's perceptions (Novalinda, 2012). There are seven (7) principles of good governance, namely legitimacy, transparency, accountability, inclusiveness, justice, connectivity, and resilience (Lockwood, 2010). However, (Klusá et al., 2018) argued that government institutions are still unable to apply several principles, those are participation, responsiveness, and transparency due to various inhibiting factors. Even so, other research shows that good governance can trigger anti-corruption and accountability activities within an institution (Biswas, Jana, Arya, \& Ramamritham, 2019).

The application of these principles entails obstacles, especially in the management of higher education in order to increase competitiveness at the international level. Therefore, the concept of self gover-nance is a branch of the concept of good governance that can be implemented in universities as 
public institutions (IFAC, 2001). According to Brunner (2011), success-ful higher education is those that can manage their own self-governance, which is in terms of management and institution to adapt to the development. Strengthening self-governance can be done by establishing various committees that can accelerate performance in various subsections of the institution (Busse, Blümel, Knieps, \& Bärnighausen, 2017; Maher, Maher, Andersson, \& Andersson, 2000; Mangunyi, 2011; Mohammed, 2012). This concept is carried out at universities in Indonesia through the concept of the legal entity of education which is now a public service agency. Higher education institutions that have become Public Service Agency (BLU) are given the authority to manage their own finances with a variety of significant changes that allow higher education performance to be more flexible and accelerated. The implementation of good governance can improve the relationship between the institution and the government (Azizah, Abidin, \& Ahmad, 2007). The involvement of organizations implementing self-governance has increased the level of satisfaction with the performance of these institutions(Lu, Sajiki, \& Yagi, 2020). Even so, implementing self-governance requires knowledge, willingness, and expertise from the institution to manage its own body for the sake of sustainability (Busse et al., 2017). More than that, knowledge about how good governance implemented in Indonesia is still quite low (Thomas S. Kaihatu, 2006).

\section{Method}

This research was conducted with a qualitative approach and the research design used case study, which is multi-site, as the settings studied have the same characteristics. The empirical material was produced through in-depth interviews with several actors involved in the conception and implementation of the internationalization and university independence policies. The empirical material in this study is related to the internationalization policy of higher education, the democratization of higher education, and the relationship between stakeholders in higher education governance. The scope of research is limited to the policy/legal framework for the governance of internationalization of higher education institutions, both state universities (PTN) and private universities (PTS).

The presence of researchers here was intended as an attempt to understand the meaning of events and interactions of people in certain situations. For that, we need order and appreciation of researchers directly to the subject in the field. The researcher in this case acts as a key instrument (Bogdan \& Biklen, 1998).

Data sources used primary sources, comprising data sources that directly provide data to researchers, while secondary data sources used data sources that do not directly provide data, including other people, for instance, leaders of universities outside the three colleges of these research subjects or through documents, covering Strategic Plan (Vision, Mission, Goals) of higher education and so on. The research informants were all university leaders and related ranks who understand and are directly involved with the problems being researched, including Chancellor, Vice Chancellor for academic affairs, Vice Chancellor for administration and finance, Vice Chancellor for student affairs, Vice Chancellor for cooperation, Head of Public Relations, Head of Academic Administration Bureau, Head of General Administration Bureau, Head of Quality Assurance Center (QAC), Head of Library, Dean, Head of Study Program, all lecturers, students, and guardians/parents of students. 
Data collection was carried out using snowball sampling, a sampling used to obtain as much information as possible, but not for generalizations. Obtaining information is very much influenced by the situation, subject, informant, and time.

In this study, three data collection techniques were employed, namely participant observation, in-depth interviews, and document study (Bogdan \& Biklen, 1998; Nasution, 1996). Data analysis is basically the process of systematically reviewing and compiling all interview transcripts, field notes, and other research materials (Bogdan \& Biklen, 1998). Data analysis consists of testing, categorizing, tabulating, or recombining empirical evidence to construct the initial propositions of a study (Yin, 1984). The study used two types of data analysis: (1) on-site data analysis and (2) cross-site data analysis. To obtain valid findings and interpretations as well as guaranteed credibility, the presence of researchers at the research site needs to be tailored to the needs, for example, for the needs of in-depth observation, triangulation (using several sources, methods, researchers, and theories), peer discussions, negative case analysis, and tracking of the sustainability of the results. Then, researchers check whether the findings can be transferred to another setting (transferability), is dependent on context (dependability), and whether or not the findings can be confirmed to the source (confirmability).

Data credibility checks were conducted using triangulation techniques, member checking, and peer discussion. The triangulation includes techniques and data collection triangulations, as well as data source triangulation. Triangulation of data collection was completed by comparing data or information collected through other techniques. While triangulation of data sources was administered by asking the truth of certain data or information obtained from an informant to another informant.

Two techniques used in checking the data credibility are member checking and peer discussion. Member checking was conducted by displaying data or information written in the format of field notes or interview transcripts, including the researchers' interpretation of the data to the informants so that those data can be commented on for approval or rejection, maybe even added or reduced. Meanwhile, peer discussions were carried out by discussing data and findings in the field with one or more peers. Peers invited to the discussion are colleagues with great attention to the research problem and have sufficient knowledge of the research method.

The research stages were carried out as follows: First, data collection was conducted at each site. Second, the data collected were studied, coded, and carried out by analyzing the categories evolving in the theme so that those would be developed into tentative conceptual findings. Furthermore, thirdly, based on the conceptual findings, the analysis was carried out through comparisons and conceptual development. Through these steps, it is expected that a more robust and abstractable conceptual findings could be obtained. To obtain the latest findings, a modified analytical induction method was employed as a way to develop and test a theory (Bogdan \& Biklen, 1998).

The induction method was done by following these steps: 1) at the beginning of the study, a raw definition and a certain phenomenon are developed; 2) leave definitions and explanations to apply until the collected data are obtained; 3) modify the definitions and explanations formulated; 4) searching for cases coming to mind that do not fit the formula; and 5) redefine the phenomenon by rearranging the explanation 
until a complementary relationship is obtained.

\section{Result and Discussion}

In the process of internationalization of higher education, the policies needs to be stated or raised declaratively in the vision of the university. Vision is a series of sentences that state the ideals or dreams of an organization or institution to be achieved in the future. In other words, a vision is a statement of want to be of an organization or institution. These findings complement the theory that the international governance process needs to be defined in a mission declared in a statement and may use different terms. It is following the theory in the preparation of the vision, mission, and objec-tives of organizing the institution that, in order to carry out the vision and mission, it must be derived in the form of objectives described in detail and the three research sites have determined their goals that are not only declared at the national level but also at the international level.

The quality policy is stated in the form of a document that contains definitions, concepts, objectives, strategies, various quality standards and/or derived quality standards, quality priorities, and objectives. Quality guidelines (manual) are manuscripts/ documents/ books containing mechanisms for planning, implementing, controlling, and developing or improving quality standards, guidelines, or procedures/work instructions for internal stakeholders who will carry out the mechanism. This is per Government Regulation (PP No. 19 of 2005). However, the Quality Policy set by each site shows different characteristics, the focus of the quality policy was largely determined by the point of view and emphasis of 'quality' selected from each site but still directed at the international or global level. One instance is to be able to develop integration interconnection of
Islamic and scientific studies, to produce graduates with high competitiveness and noble character. The performance of the Islamic university students needs to be improved (Sedighi \& Mehrdad, 2014) even though the parents/guardians are satisfied with the respective Islamic university (Yeon, Kamaruddin, Harun, \& Kusumawardani, 2019). In terms of quality improvement, the emergence of financial institutions is encouraged to support (Belabes, Belouafi, \& Daoudi, 2015).

Governance arranged in the framework of the internationalization process of higher education needs to be outlined and elaborated in the form of a vision, mission, objectives and strategic plans, quality policies, and quality objectives; although the vision, mission, goals, and strategic plans used by universities have various directions and variations, as well as various target schedule for achievement. The research study obtained theoretical findings which were formulated into a proposition that the implementation of the internationalization of higher education needs to be stated in governance documents because it will be used as a guide towards achieving the objectives of the internationalization process.

Because the implementation of internationalization has very broad intersectoral links and a high level of integrity, as well as a very complex dimension, the internationalization program requires management by institutions/ fields/ offices/ units specifically, where this institution functions to manage international programs, handle international cooperation programs, ensure the implementation of effective, efficient as well as focused international cooperation, coordinate and develop international programs more broadly, manage cooperative activities involving foreign parties, implement New Student Admissions 
(PMB), handle promotion programs, and is as the implementers of the international cooperation program. The establishment of this particular institution/ field/ office/ unit is to anticipate and fulfil the development needs of internationalization program activities which are increasingly ubiquitous and require special handling, in addition to the fact that the existing units are limited to authority and responsibility. This new unit was created as a refinement of the existing International Office. The facts indicate that the internationalization process remains suffering some obstacles (Metsola, Leppäaho, \& Paavilainen-mäntymäki, 2020). The political issue may contribute to this situation (Bamberger, Morris, Weinreb, Yemini, \& West, 2018).

The curriculum and learning process developed in the context of internationalization at the international level are varied. This diversity includes the name of the course, the distribution of the course, the number of credits, as well as the syllabus and literature books in the learning process and administrative models. These complement and expand the theory that in the process of internationalization, one of the aspects that need to be developed is curriculum changes, in this case, curriculum internationalization. However, curriculum changes (curriculum internationalization) obviously depend on how the study program formulates policy.

Thus, these findings provide broader explanatory and forecasting power that governance formulated in the context of the internationalization process of higher education is described and fotified in the form of quality assurance. Quality assurance used by universities at the international level is varied, as well as the process of building assurance. Quality has different styles so that orientation changes in guarding quality assurance will also exhibit diversity.
Orientation changes in guarding quality assurances also have diversity due to some factors such as the policy (Holm, Sammalisto, \& Vuorisalo, 2015) and government ambiguity (Capano, 2014). Quality assurance is aimed at using Information technology (IT) as the main target, quality standards are built through ISO standards, developed with the courage to recruit foreign lecturers and accept foreign students, competition policy is based on a global level with foreign universities, quality assurance starts with a change in orientation (mindset), which is a shifting from inward looking to outward looking by seizing the target to become World Class University, and quality assurance is carried out with certain steps and strategies.

The quality of higher education outcomes is expressed as the competitiveness of these outcomes in gaining recognition from the world of science at the international level. This quality is characterized, among others, by the ability to penetrate international publications, the ability of graduates to compete in the global arena, and the ability to win academic awards at the international level such as the Nobel Prize or other awards. Relevance, on the other hand, measures the level of conformity between the products produced by higher education institutions (both in the form of graduates and research and development results) and the needs of those who use these products, including government, society, and industry. Relevant and quality higher education programs are characterized by the ability of graduates to meet the needs of the job market, create new jobs, or develop knowledge according to global knowledge developments.

This finding supports Scott P's theory stating that the growth in demand for higher education internationally and principally is influenced by changes in natural universities in the new millennium era, most likely the 
choice is the expansion of human resource allocation which can provide a direct trend and the possibility of expansion. The allocation includes: 1) internationalization of the university, including the use of conversation in English, especially in OECD countries; 2) offshore campuses (distance campuses); 3) technology (a combination of Information Technology/IT); 4) university 21 (21st century university); 5) Accreditation and Quality Assurance (accreditation and quality assurance); and 6) A Vision of the Culture of University in the New Millennium (Vision of University Culture in the New Millennium Era). Thus, it can be concluded that the sustainability of the internationalization program is escorted by various programs including quality assurance programs, cooperation programs with foreign universities, foreign student admissions programs, and international study programs. The growth in demand for higher education internationally and principally is influenced by natural changes in universities in the new millennium era (Scott P in David and Olsen, 2000).

Collaboration to support the internationalization process of higher education is conducted through lecturer exchange programs, building volunteer programs, student exchanges, opening double degree programs, and research collaboration. These findings indicate that the cooperation carried out by universities in the internationalization process refers to as existing or developing theories but there are programs carried out by universities in an effort to complement existing forms of cooperation, or describe other forms of cooperation from existing collaborations, such as, volunteer programs. Volunteers are not only students but also foreigners who take part in a program from one of the voluntary organizations/institutions collaborating with universities, one of which is teaching languages and skills in abroad as part of cooperation with universities such as student exchange (Torralba, Domínguez, María, Campo, \& López, 2012) and in-service teacher mobility that proves the beliefs and practices in teaching (He, Lundgren, \& Pynes, 2017).

Hence, it can be concluded that according to the existing theory and given the findings on the three sites, a university will be acknowledged as a world-class university if earns position in one or more ranking of institutions/universities at the world level (World University Ranking). Although many world institutions provide facilities and criteria and methodologies, universities do not necessarily follow all the alternatives offered by all the world's institutions but choose according to what has been achieved at that time and based on the approach desired.

In general, the process of internationalization of higher education uses the concept of self-governance, which is reflected in the flowchart below: 


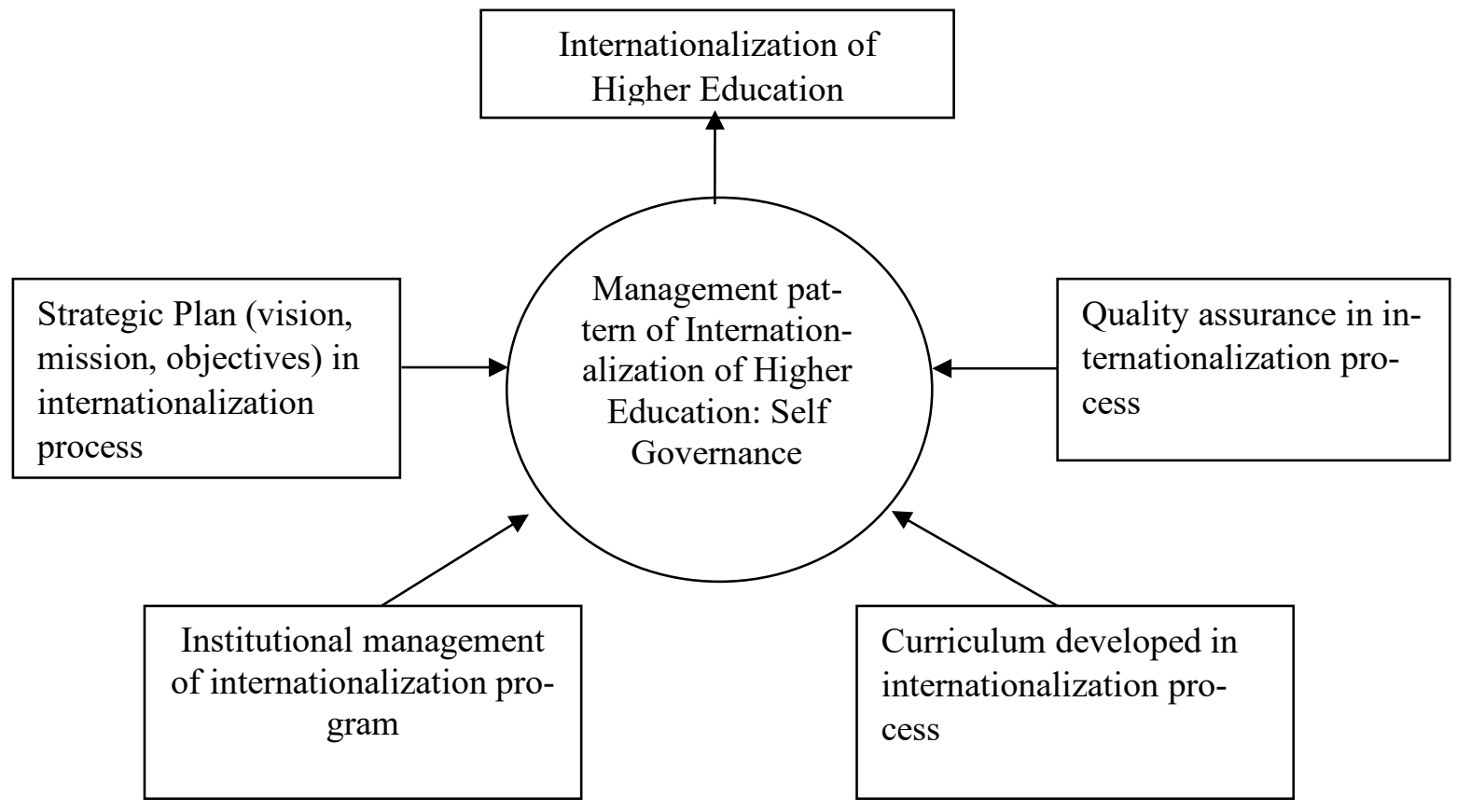

Figure 1 Self-Governance of Higher Education in Indonesia

a. The Implementation of Self-Governance in The Context of The Vision and Mission of Higher Education

Following the concept of the Public Service Agency (BLU), universities are allowed to regulate the institution based on their needs. BLU management is not only in finance aspect, but also in designing the vision, mission, and goals of higher education institutions that are created, managed and implemented independently by universities. The following is a summary of the vision, mission, and goals of several universities that implement the concept of self-governance for the purpose of internationalization:

Table 1 The Main Vision of Internationalization Using Self-Governance Concept

\begin{tabular}{ll}
\hline \multicolumn{1}{c}{ Vision } & \multicolumn{1}{c}{ Meaning } \\
\hline $\begin{array}{l}\text { Realizing higher education that is superior in academics, } \\
\text { professional management, and effective, efficient, and } \\
\text { accountable in education. }\end{array}$ & $\begin{array}{l}\text { Higher education improves its quality and } \\
\text { competitiveness before increasing its status } \\
\text { to become an internationally competitive } \\
\text { university }\end{array}$ \\
$\begin{array}{l}\text { The vision applies the 'rahmatan lil alamin' and 'to have the Aconcept in Islam which is ablessing for the } \\
\text { advantage of the same level with quality universities in universe is the embodiment of a university } \\
\text { developed countries' }\end{array}$ & $\begin{array}{l}\text { that must be able to bring benefits } \\
\text { internationally }\end{array}$ \\
\hline
\end{tabular}

These visions are a reflection of the concept of self-governance and the internationalization of higher education. Strengthening this vision is essential because improving the performance of an institution is determined by how the leadership of the institution can implement and promote selfgovernance (Arshad, Abdul, \& Abu, 2014). Furthermore, participation in applying the vision is an important factor in institutional reform within the framework of selfgovernance (Speer, 2012), including in higher 
education. Meanwhile, the internationalization mission is reflected as follows:

Table 2 The Main Mission of the Internationalization of Higher Education in the Context of Self-Governance

\begin{tabular}{|c|c|}
\hline Mission & Meaning \\
\hline $\begin{array}{l}\text { Improving the quality of research, learning, and community } \\
\text { development through human resource development, } \\
\text { developing sound and harmonious management and } \\
\text { institutional systems, and expanding creative and innovative } \\
\text { collaborative networks leading to world-class universities. }\end{array}$ & $\begin{array}{l}\text { Research and development of human } \\
\text { resources (SDM) is oriented to international } \\
\text { competitiveness }\end{array}$ \\
\hline $\begin{array}{l}\text { Mission oriented to international, using the term 'increasing } \\
\text { human dignity as an effort to uphold human values and } \\
\text { civilization'. }\end{array}$ & Wider coverage of benefit of the university \\
\hline
\end{tabular}

One of the missions in internationalization that becomes the focus is harmonious management and institutions. This concept is derived from the concept of good governance where among the principles are accountability (Lockwood, 2010) and fairness (El \& Kairouz, 2014). The application of the concept of self-governance certainly requires willingness and expertise in implementing this internationalization mission. This implementation will face various challenges that require special expertise from management to achieve vision and mission (Arshad et al., 2014).

\section{b. Self-Governance in The Context of Institutional Management}

Self-governance in Indonesian universities is reflected in the applicable institutional management. This process is intended to achieve the internationalization of higher education.
The management of this internationalization needs to be meticulously done considering the risk arising from the internalization policy, including political risks and country risks (Eduardsen \& Marinova, 2020). Both of these risks have a far-reaching impact on selfgovernance for internationalization. For instance, the existence of internationalization has the possibility of political rules and policies collision which may not accommodate and even lead to controversy (Bamberger et al., 2018). Also, the risk of losing competitiveness with more developed countries is quite a challenge. However, with good management, internationalization can improve the performance of institutions (Rienda, Claver, $\&$ Andreu, 2020), including universities. The existence of international cooperation bureaus with various forms in universities facilitates the management and internationalization process carried out by the universities.

The summary of institutional management is reflected as follows: 
Institutional management (management system) of higher education international program
The management of the international program is given to the Cooperation Bureau (Head of the Cooperation Bureau), with the task of managing cooperation, including managing international cooperation (submitted to the Head of International Cooperation)

The international program is managed under the university, by the Dean International Programme. Previously, it was managed by each faculty as the administrator of the international program.

Figure 2 Flow of Internationalization of Higher Education (Institutional Management) Using Self-Governance Concept

c. Self-Governance in The Context of International Competitive Learning

The management of learning and curriculum that is internationally competitive is compiled based on the vision, mission, objectives, and the management of the institution which is independently aimed at developing world class universities. The following are the results of the research related to the internationalization of learning and curriculum in higher education:

Table 3 Internationalization of Learning and Curriculum

\begin{tabular}{ll}
\hline \multicolumn{1}{c}{ Aspects } & \multicolumn{1}{c}{ Aspects of Internationalization } \\
\hline Form of learning & Establish an international study program \\
Courses & Use of English in several subjects. However, it is still limited to \\
& the name of the course and the 1 instruction in English. \\
Internationalization process & Starting from the study program to the faculty. However, some \\
& have established ad hoc such as the Office for International \\
& Relations \\
\hline
\end{tabular}

In the aspect of learning forms, the formation of an international study program is one of the first steps. With this international study program, it is expected that it can attract foreign students to apply. The introduction of this program will certainly escalate the name of the university at the international level. However, as aforementioned, the internationalization process will experience challenges due to various views (Foster \& Carver, 2018). The current internationalization tends to be on the curriculum content, not on the pedagogy. 
Internationalization development needs to pay attention to technology and supporting platforms so that this program can attract the interests of various parties (Costa, Lucas, Pinho, \& Sousa, 2020).

\section{d. Self-Governance in The Context of Quality Assurance}

In the aspect of quality assurance, the independent regulation by universities directs every guarantee to internationalization through various forms. The forms of quality assurance are as follows:

Table 4 Quality Assurance

\begin{tabular}{|c|c|}
\hline Aspect & Quality \\
\hline Technology & $\begin{array}{l}\text { Guarantee of lecturer's publications through online journals, } \\
\text { financial control, and human resources using information } \\
\text { technology }\end{array}$ \\
\hline
\end{tabular}

ISO Standard

Recruitment of foreign lecturers and foreign students, improving the quality of lecturer recruitment selection, as well as competitions that are based on a global level with foreign universities

Orientation change

Shifting the orientation from Inward Looking to Outward Looking with the target of becoming a World Class University through refining Teaching University towards Research University.

The technology aspect is an important factor in improving higher education performance. The results show that the use of information technology has a direct and indirect impact on the performance of an institution (Akbar, Abbaspour, \& Abachian, 2013; Shahzad, Du, Khan, Shahbaz, \& Murad, 2020). Improvements in technology will ultimately improve the quality of graduates (Epie et al., 2020). As matter of fact, Indonesia has planned open education resources (OES) through the use of technology (Fitriansyah, Fatinah, \& Syahril, 2020). The use of this technology is also used to increase student's activity in learning (Thambu, Prayitno, \& Zakaria, 2021).
Therefore, the use of information technology is a major factor in the internationalization of higher education within the framework of self-governance university.

Furthermore, despite entrepreneurial leadership being a mediator in the governing university (Wahab \& Tyasari, 2020), working in the millennial era also gives more challenges. In the form of implementing good governance, the university leader must be aware that Information Technology (IT) is a part of their leadership role (Au-YongOliveira, Gonçalves, Martins, \& Branco, 2018). The leadership style in the millennial era is described as follow: 


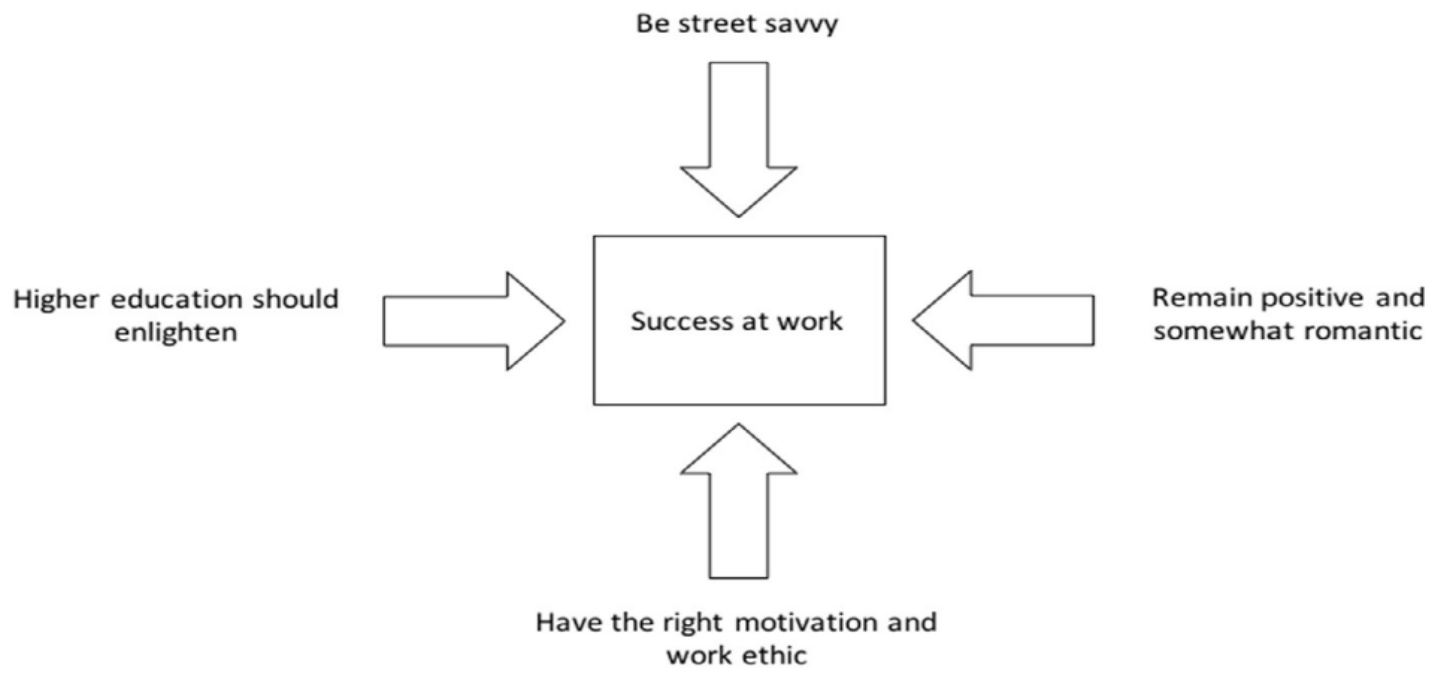

Be an authentic leader

Significant change in leadership style under millennial managers who interact much more with technology and are thus more democratic and transparent due to this factor

Figure 3 Leadership Style Under Millennial Managers

(Au-Yong-Oliveira et al., 2018)

This model offers some changes to the university leader to adjust their leadership style appropriately to the Millennials' thoughts. Implementing self-governance in the concept of good university governance might be challenging without considering the current generation style.

The technology also brings five major changes in education (Burbules, Fan, \& Repp, 2020): (a) educational aims; (b) educational ecologies; (c) the process of learning; (d) the process of teaching; and (e) educational governance and policy.

Advanced education must implement technology in university governance. The leader should change their educational objectives following the rapid changes and must be adaptive, focusing on flexibility. This notion is an answer to the unpredictable changes in people's lives as in the impact of technology. The university's transformation aims to bring the shifting of the ecologies, the teaching and learning process, and finally, the academic self-governance and policy.
Following the concept of internationalization, recruitment is not only limited to foreign students but also foreign lecturers as an important factor. This is not something debatable because the presence of foreign lecturers will enrich our knowledge and be able to align the quality of higher institutions in Indonesia with those of overseas. This policy will also have an impact on the university's goal of becoming a world class university through the stages of teaching university and research university.

Last but not least, the management of higher education needs to take into account the advantages that differentiate it from other universities or even education in other countries. Amidst the complex competencies of graduates in the future (Fernandez, Lara, Ugalde, \& Sisodia, 2018), one of the important factors in higher education management today is the distinctiveness of hospitality management education (Lugosi \& Jameson, 2017). When connected with the Indonesian context, politeness speech acts are a culture that is always put forward. A study 
shows that the way of speaking directly to the college community is strongly influenced by socio-cultural factors (Fatma, Prayitno, Jamaludin, Jha, \& Badri, 2019). Especially in a country where access to education is quite hindered by financial factors (Sabic-ElRayess, 2019), the higher education management is more complex. Therefore, the adaptation of politeness in higher education management based on local wisdom in Indonesia is very important.

\section{Conclusion}

The results of the study show that the governance structure in the internationalization is described in the form of: a. vision, mission, objectives, and strategic plans, quality policies and quality objectives that are oriented towards international quality; b. the management of international programs is generally given to an institution/ field/ office/ unit that specifically manages interna tional programs; c. the curriculum and lear ning process developed are compiled with different models and trends; and $\mathrm{d}$. gover nance in the context of internationalization is described and guarded in the form of quality assurance

\section{References}

Akbar, A., Abbaspour, A., \& Abachian, R. (2013). The Effect of Information Technology on Organizational Structure and Firm Performance: An Analysis of Consultant Engineers Firms ( $\mathrm{CEF}$ ) in Iran. Procedia - Social and Behavioral Sciences, 81 (2005), 644-649. https://doi.org/10.1016/j.sbspro.2013.06 .490

Albassam, B. A. (2019). Building An Effective Knowledge Management System in Saudi Arabia Using The Principles of Good Governance. Resources Policy, 64(November), 101531.

https://doi.org/10.1016/j.resourpol.2019
.101531

Arshad, R., Abdul, H., \& Abu, N. (2014). Assessing the Self-Governance and Value Creation in Non-Profit Organisations. Procedia - Social and Behavioral Sciences, 145, 286-293. https://doi.org/10.1016/j.sbspro.2014.06 .036

Au-Yong-Oliveira, M., Gonçalves, R., Martins, J., \& Branco, F. (2018). The social impact of technology on millennials and consequences for higher education and leadership. Telematics and Informatics, 35(4), 954-963. https://doi.org/10.1016/j.tele.2017.10.00 7

Azizah, N., Abidin, Z., \& Ahmad, H. N. (2007). Corporate Governance in Malaysia: the Effect of Corporate Reforms and. Asian Academy of Management Journal, 12(1), 23-34.

Bamberger, A., Morris, P., Weinreb, Y., Yemini, M., \& West, T. (2018). International Journal of Educational Development Hyperpoliticised Internationalisation in A Pariah University: An Israeli institution in the occupied West Bank. International Journal of Educational Development, (July), $\quad 0-1$. https://doi.org/10.1016/j.ijedudev.2018. 09.005

Belabes, A., Belouafi, A., \& Daoudi, M. (2015). Designing Islamic Finance Programmes in A Competitive Educational Space: The Islamic Economics Institute Experiment. Procedia - Social and Behavioral Sciences, 191, 639-643. https://doi.org/10.1016/j.sbspro.2015.04 .300

Bernal, G. L., \& Penney, J. (2019). Scholarships and Student Effort: Evidence from Colombia's Ser Pilo Paga Program. Economics of Education Review, 72(November 2018), 121-130. https://doi.org/10.1016/j.econedurev.20 19.04.008

Biswas, R., Jana, A., Arya, K., \& Ramamritham, K. (2019). A Good- 
Governance Framework for Urban Management. Journal of Urban Management, $\quad 8(2), \quad 225-236$. https://doi.org/10.1016/j.jum.2018.12.0 09

Burbules, N. C., Fan, G., \& Repp, P. (2020). Five Trends of Education and Technology in A Sustainable Future. Geography and Sustainability, 1(2), 9397.

https://doi.org/10.1016/j.geosus.2020.05 .001

Busse, R., Blümel, M., Knieps, F., \& Bärnighausen, T. (2017). Series Germany and Health 1 Statutory Health Insurance in Germany : A Health System Shaped by 135 Years Of Solidarity, Self-Governance, and Competition. The Lancet, $6736 \quad$ (17), 1-16. https://doi.org/10.1016/S01406736(17)31280-1

Capano, G. (2014). The Re-Regulation of The Italian University System Through Quality Assurance: A Mechanistic Perspective. Policy and Society, 33(3), 199-213.

https://doi.org/10.1016/j.polsoc.2014.08 .001

Costa, E., Lucas, A., Pinho, J., \& Sousa, D. (2020). Industrial Business Associations Improving The Internationalisation of Smes with Digital Platforms: A Design Science Research Approach. International Journal of Information Management, 53(December 2019), 102070.

https://doi.org/10.1016/j.ijinfomgt.2020. 102070

Eduardsen, J., \& Marinova, S. (2020). Internationalisation and Risk: Literature Review, Integrative Framework and Research Agenda. International Business Review, (November 2019), 101688.

https://doi.org/10.1016/j.ibusrev.2020.1 01688

El, J., \& Kairouz, A. (2014). Euro-Med : Public Management and Good Local Governance. Procedia - Social and Behavioral Sciences, 124, 528-535. https://doi.org/10.1016/j.sbspro.2014.02 .516

Epie, R., Robert, J., Kamdjoug, K., Business, T. B. S., Alphonse, P., Cs, J., \& Cedex, T. (2020). International Journal of Information Management The role of Digital Information Use on Student Performance and Collaboration in Marginal Universities. International Journal of Information Management, 54 (May),

102179. https://doi.org/10.1016/j.ijinfomgt.2020. 102179

Fadhil, I., \& Sabic-El-Rayess, A. (2021). Providing Equity of Access to Higher Education in Indonesia: A Policy Evaluation. Indonesian Journal on Learning and Advanced Education (IJOLAE), 3(1), 57-75. https://doi.org/10.23917/ijolae.v3i1.103 76

Fatma, F., Prayitno, H. J., Jamaludin, N., Jha, G. K., \& Badri, T. I. (2019). Directive Speech Acts in Academic Discourse: Ethnography of Communication from Gender Perspective in Higher Education. Indonesian Journal on Learning and Advanced Education (IJOLAE), 2(1), 27-46.

https://doi.org/10.23917/ijolae.v2i1.882 9

Fernandez, A. I., Lara, P. R., Ugalde, M. C., \& Sisodia, G. S. (2018). Distinctive Competencies and Competency-Based Management in Regulated Sectors: A Methodological Proposal Applied to The Pharmaceutical Retail Sector in Spain. Journal of Retailing and Consumer Services, 42(September 2017), 29-36. https://doi.org/10.1016/j.jretconser.2018 .01 .007

Fitriansyah, R., Fatinah, L., \& Syahril, M. (2020). Critical Review: Professional Development Programs to Face Open Educational Resources in Indonesia. Indonesian Journal on Learning and Advanced Edcuation (IJOLAE), 2(2), 109-119.

https://doi.org/10.23917/ijolae.v2i2.966 2 
Foster, M., \& Carver, M. (2018). The International Journal of Explicit and Implicit Internationalisation: Exploring Perspectives on Internationalisation In A Business School with A Revised Internationalisation of The Curriculum Toolkit. The International Journal of Management Education, 16(2), 143153.https://doi.org/10.1016/j.ijme.2018. 02.002

He, Y., Lundgren, K., \& Pynes, P. (2017). Impact of Short-Term Study Abroad Program: Inservice Teachers' Development of Intercultural Competence and Pedagogical Beliefs. Teaching and Teacher Education, 66, 147-157.

https://doi.org/10.1016/j.tate.2017.04.01 2

Holm, T., Sammalisto, K., \& Vuorisalo, T. (2015). Education for Sustainable Development and Quality Assurance in Universities in China and the Nordic Countries: A Comparative Study. Journal of Cleaner Production, 107, 529-537.

https://doi.org/10.1016/j.jclepro.2014.0 1.074

Klusá, P., Alexandrescu, F., Osman, R., Kunc, J., Dvo, P., Frantál, B., ... Skokanová, H. (2018). Land Use Policy Good Governance as A Strategic Choice in Brown Fi Eld Regeneration: Regional Dynamics from the Czech Republic, 73 (December 2017), 29-39. https://doi.org/10.1016/j.landusepol.201 8.01 .007

Li, X., Sanders, K., \& Frenkel, S. (2012). How Leader-Member Exchange, Work Engagement and HRM Consistency Explain Chinese Luxury Hotel Employees' Job Performance. International Journal of Hospitality Management, 31(4), 1059-1066. https://doi.org/10.1016/j.ijhm.2012.01.0 02

Lockwood, M. (2010). Good Governance for Terrestrial Protected Areas: A Framework, Principles and Performance Outcomes. Journal of Environmental
Management, $91 \quad$ (3), 754-766. https://doi.org/10.1016/j.jenvman.2009. 10.005

Lorenz, M. P., Ramsey, J. R., \& Richey, R. G. (2018). Expatriates' International Opportunity Recognition and Innovativeness: The Role of Metacognitive and Cognitive Cultural Intelligence. Journal of World Business, 53(2),

222-236. https://doi.org/10.1016/j.jwb.2017.11.0 04

Lu, Y., Sajiki, T., \& Yagi, N. (2020). Factors Affecting Fisherman Satisfaction with Fishermen's Self-Governance Organizations: A Case Study of the Taiwan Donggang Sakuraebi (Sergia Lucens) Production and Management Group. Marine Policy, 115 (November 2019),

103819. https://doi.org/10.1016/j.marpol.2020.1 03819

Lugosi, P., \& Jameson, S. (2017). Challenges in Hospitality Management Education: Perspectives from the United Kingdom. Journal of Hospitality and Tourism Management, 31, 163-172. https://doi.org/10.1016/j.jhtm.2016.12.0 01

Maher, M. E., Maher, M. E., Andersson, T., \& Andersson, T. (2000). Corporate Governance: Effects on Firm Performance and Economic Growth. SSRN Electronic Journal, (February). https://doi.org/10.2139/ssrn.218490

Mangunyi, E. E. (2011). Ownership Structure and Corporate Governance and Its Effects on Performance: A Case of Selected Banks in Kenya. International Journal of Business Administration, 2(3), 2-18. https://doi.org/10.5430/ijba.v2n3p2

Metsola, J., Leppäaho, T., \& Paavilainenmäntymäki, E. (2020). Process in Family Business Internationalisation: The State of The Art and Ways Forward. International Business Review, (November 2019), 101665. https://doi.org/10.1016/j.ibusrev.2020.1 01665 
Mohammed, F. (2012). Impact of Corporate Governance on Banks Performance in Nigeria. Journal of Emerging Trends in Economics and Management Sciences, 3(3), 257-260.

Novalinda, Y. (2012). Public Perception on The Implementation of Good Governance and Relationship with Performance (Case Study: City Government Administration South Jakarta ), (X).

Rienda, L., Claver, E., \& Andreu, R. (2020). Journal of Hospitality and Tourism Management Family Involvement, Internationalisation and Performance: An Empirical Study of the Spanish Hotel Industry. Journal of Hospitality and Tourism Management, 42 (August 2019), 173-180. https://doi.org/10.1016/j.jhtm.2020.01.0 02

Sabic-El-Rayess, A. (2019). Role of Education in Financial Inclusion of Poor and Unbanked Women in India. Indonesian Journal on Learning and Advanced Education (IJOLAE), 1(2), 72-90. https://doi.org/10.23917/ijolae.v1i2.841 3

Sedighi, M., \& Mehrdad, A. G. (2014). The Productivity Indexes at Islamic Azad University, Hamedan Branch, Iran. Procedia - Social and Behavioral Sciences, 131, 244-247. https://doi.org/10.1016/j.sbspro.2014.04 .111

Shahzad, F., Du, J., Khan, I., Shahbaz, M., \& Murad, M. (2020). Untangling the Influence of Organizational Compatibility on Green Supply Chain Management Efforts to Boost Organizational Performance Through Information Technology Capabilities. Journal of Cleaner Production, 266, 122029.

https://doi.org/10.1016/j.jclepro.2020.1 22029

Speer, J. (2012). Participatory Governance Reform : A Good Strategy for Increasing Government Responsiveness and
Improving Public Services? World Development, 40(12), 2379-2398. https://doi.org/10.1016/j.worlddev.2012 .05 .034

Stough, T., Ceulemans, K., Lambrechts, W., Cappuyns, V., Ceulemans, K., Lambrechts, W., \& Cappuyns, V. (2017). Assessing Sustainability in Higher Education Curricula: A Critical Reflection on Validity Issues. Journal of Cleaner Production. https://doi.org/10.1016/j.jclepro.2017.0 2.017

Thambu, N., Prayitno, H. J., \& Zakaria, G. A. N. (2021). Incorporating Active Learning into Moral Education to Develop Multiple Intelligences: A Qualitative Approach. Indonesian Journal on Learning and Advanced Education (IJOLAE), 3(1), 17-29. https://doi.org/10.23917/ijolae.v3i1.100 64

Thomas S. Kaihatu. (2006). Good Corporate Governance dan Penerapannya di Indonesia. Jurnal Manajemen dan Kewirausahaan, 8(1), pp.1-9. https://doi.org/10.9744/jmk.8.1.pp. 1-9

Torralba, R., Domínguez, R., María, J., Campo, del, \& López, L. (2012). Foreigner? Want to Study in Spain? The Integration Process at Universities. Procedia - Social and Behavioral Sciences, 69(Iceepsy), 549-557. https://doi.org/10.1016/j.sbspro.2012.11 .445

Wahab, A., \& Tyasari, I. (2020). Entrepreneurial Leadership for University Leaders: A Futuristic Approach for Pakistani HEIs. Asia Pacific Management Review, 25(1), 5463.

https://doi.org/10.1016/j.apmrv.2019.09 .002

Yeon, A. A. A., Kamaruddin, A. I., Harun, N. A., \& Kusumawardani, A. (2019). Parents' Satisfaction and The Quality of Dental Care Provided by Dental Students at International Islamic University Malaysia. Materials Today: Proceedings, 16, 2341-2350. 
https://doi.org/10.1016/j.matpr.2019.06.

131

Van Der Wende., Marijk. 2007.

Internationalization of Higher

Education in the OECD Countries:

Challanges and Opportinities for the

Coming Decade. Journal of Studies in

International Education. Vol. 11, hlm 274-289.

Warner, D., Palmfreman, D. 2009. Higher

Education Management the Key Elements. Buckingham: The Society for Research into Higher Education (SRHE) \& Open University Press.

Yin, R.K (1984) Case Study Research:

Design and Methods. Sage Publications, Beverly Hills, California. 